Article

\title{
The Effect of Entry into the European Union on the Slovak Beer Industry and Its Consequences for the Tax Taken from the Excise Duty on Beer
}

\author{
Ing. Juraj Válek \\ Department of Finance, Faculty of National Economics, University of Economics in Bratislava, \\ Dolnozemská cesta 1, Bratislava 852 35, Slovakia; E-Mail: valek.euba@gmail.com; \\ Tel.: +421-2-6729-1340
}

Academic Editor: Edgar Chambers IV

Received: 11 August 2015 / Accepted: 13 November 2015 / Published: 25 November 2015

\begin{abstract}
The following paper is concerned with the issue of increasing the excise duty on beer and its consequences for consumption of the studied product. The aim is to demonstrate the tax burden in relation to domestic producers and beer consumption in the domestic market. The time period considered is the 16 years from 1999 to 2014. Data on consumption and the evolution of excise duty rates were compared ex post and conclusions were drawn using an analysis of economic indicators. In general, it is the case that, by increasing the rates of the duty, governments expect to see an increase in the income side of the state budget, even though increases in tax lead to reductions in consumption. This is, however, only a short-term effect and, over a longer time frame, such measures have a negative effect not only on consumption, but also on domestic production and on the tax income in the state budget.
\end{abstract}

Keywords: elasticity; optimal taxation; rates of excise duty; beer consumption

\section{Approaches to Excise Duties on Consumption}

F.P. Ramsey was the first to postulate a theory of the optimal taxation of consumption [1]. He came to the conclusion that if we ignore the expenses of collecting the taxes, then having one single tax rate for all goods is only rarely optimal. It appeared that taxing all goods at a level rate is effective because it does not lead to distortion of the relative prices of different goods. On a more detailed examination, however, he discovered that there is one special good, namely free time, that cannot be subjected to a consumption tax, and furthermore, one cannot also assume that supply curves are perfectly elastic and, 
therefore, that the consumer will put up with the full effect of the tax. On the basis of these facts, he formulated a rule whereby goods with a higher demand elasticity should be taxed at a lower rate, and goods for which demand is not elastic can be taxed at a rate set at a higher level [2]. The tax rate is therefore indirectly proportional to supply elasticity and demand elasticity. So that taxation could at least, to an extent, be equitable, he proposed setting a lower rate on goods that are consumed primarily by people with lower incomes [3]. According to O'Donoghue and Rabin [4], consumption taxes play an important role in putting consumers off consuming goods that can have negative effects on those who consume them; among these we can put alcoholic drinks, tobacco, and foods of low nutritional value. Consumption taxes levied on such goods can at least partially stop their excess consumption [5]. In the event of no consumption taxes on such goods, irrational consumers could start consuming them in excessive amounts without realizing what consequences such actions may have for them in the future [6]. The internalization of external costs can lead the consumer to make optimal decisions from the point of view of society. Ideally, consumption taxes should equal the marginal costs of the damage caused to others, which is possible if these costs are directly proportional to consumption [7].

Currently, general consumption taxes are seen as selective taxes from the sale or use of particular goods or services, for example alcohol or petrol. During the time period considered, governments relied on the income from such taxes, given that among the OECD countries such taxes contribute, on average, $12 \%$ of the total income [4]. Apart from the fact that consumption taxes produce necessary income, they also represent a means by which externalities can be managed, and those who profit from government expenditures can be taxed [8]. There are four motives justifying the very existence of consumption taxes. First, they provide income to the state budget. Secondly, they control externalities, which pollute the environment. Thirdly, they permit the application of the principle of tax utility (consumption taxes should be designed to bear on those who gain benefits from the state, which finances such benefits from particular consumption taxes, e.g., taxes on petrol which go towards financing road repairs). Lastly, they can levy a tax on those goods that damage health, such as tobacco and alcohol, where there is a risk of over-consumption if no tax was levied on them [6].

\section{The History of Beer Brewing in the Territory of Slovakia}

The history of beer brewing in the territory of Slovakia is almost as old as in the case of neighboring countries and reaches back to the turn of the 10th and 11th centuries. The first brewing guild was set up in 1450 in Bardejova and by the 17th century beer was brewed in every larger town. In the 1990s there were 15 breweries in Slovakia [9].

The Slovak beer industry underwent a number of significant changes in its history. The free movement of goods, which followed the entry of Slovakia into the European Union in 2004, had the effect of reducing beer production each year, with the result that the negative trade balance in respect to beer increased. Following the split of Czechoslovakia into Slovakia and the Czech Republic on 1 January 1993, a customs union was implemented between the two separate states, which resulted in a negative trade balance for Slovak beer from 5 to 7 million Euros [10]. However, as a result of the rapid decrease in the number of Slovak breweries and the resulting decrease in production and export of beer to the Czech Republic, the negative trade balance rapidly increased to reach 32.363 million Euros in 2014. From 1995 to 1998, new domestic as well as foreign investors entered the beer brewing industry. The 
difference between the tax rate for low-alcohol and other beer was reduced. The record for beer production, 4.8 million hectoliters, was recorded in 2002. At that time, Slovakia was in the 10th position in regards to beer consumption per head of population (Source: Slovak Association of Beer and Malt Producers [11]). This increasing trend in beer production came to a halt halfway through 2003 . The rate of tax on beer was increased twice that year. The first increase occurred on 1 January 2003 when the basis for taxation was changed ${ }^{1}$ and then again on 1 August 2003 when the rates of tax on beer were increased $^{2}$ (Table 2). This double-blow during a single year was extreme and out of proportion. The second half of 2003 constituted the start of a long-term recession in Slovak beer brewing. Whereas beer sales in the first half of 2003 were still 1\% higher than in the same period of 2002, in the last five months of 2003, from August to December, a fall of 12\% was registered compared with the same period in 2002. Over the whole year of 2003, sales were down 4.1\% compared with 2002 (Figure 1). As a result of the tax increases, as well as the opening up of the market and entry into the EU, seven Slovak breweries were shut down with a loss of 5000 jobs. During the period from 2008 to 2010, employment in the beer industry fell by $21 \%$ (Source: Slovak Association of Beer and Malt Producers [11]).

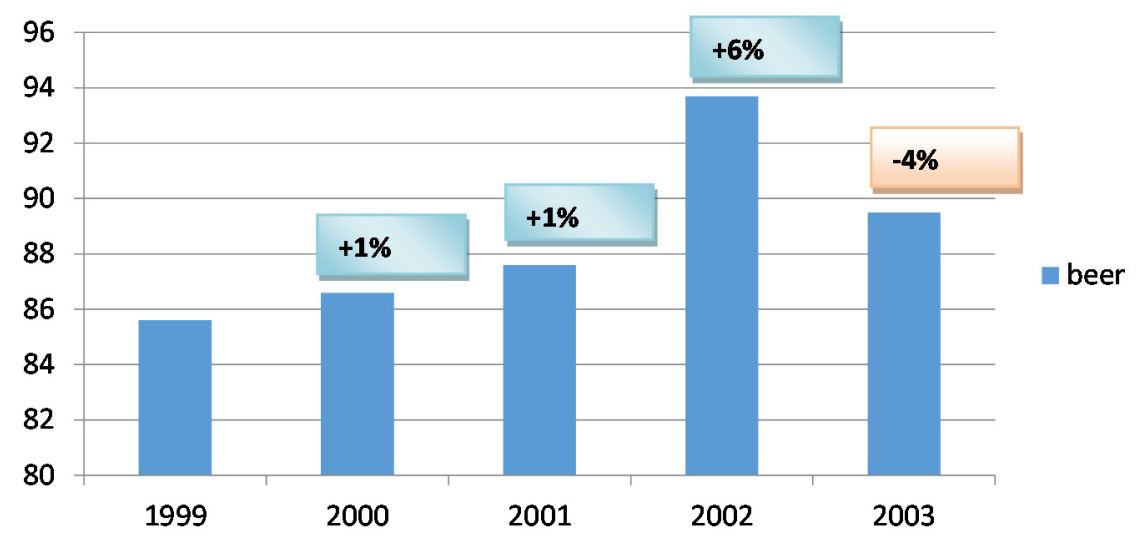

Figure 1. Beer sales from 1999 to 2003. Source: own calculations based on data from the Slovak Association of Beer and Malt Producers [11].

At the present time, over $90 \%$ of the Slovak beer market is dominated by two multinational giants and three smaller breweries. The Slovak beer market is significantly influenced by the dominance of the two largest companies, which are, in addition, foreign-owned. The number one producer, Heineken Slovakia, owned by the world's number three company Heineken International, has a $45 \%$ share, and the number two company, Pivovar Topvar, which belongs to the world's number two SABMiller, has a $28 \%$ share. The two companies, among whose brands are "Zlatý Bažant", "Corgoň", "Kelt", "Martiner" and "Gemer", and respectively "Topvar", "Šariš” and "Smädný Mních”, make up almost three-quarters of the total market. The third-largest brewer is also the oldest: Pivovar Steiger (with brands "Steiger", "Stein", "Grošák", "Sitňan"), whose majority owner is the British firm Endemit with the Czech company PMS having a minority holding [15].

\footnotetext{
${ }^{1}$ Law No. 391/2002 [12] which amended and added to Law No. 310/1993 [13] relating to excise duties on beer in accordance with later regulations.

${ }^{2}$ Law No. 242/2003 [14] which amended Law No. 310/1993 [13] relating to excise duties on beer in accordance with later regulations.
} 
The three companies mentioned, together with the Banskobystrický Pivovar (brands: "Urpiner" and "Kaprál") and the Bytča brewery Popper owned by Slovak entrepreneurs, complete the five dominant players. It is important, though, that up to $85 \%$ of the raw materials used by the top three players (Heineken, Topvar, Steiger) come from Slovakia. The global companies brought in investments to update the industry, as well as technical innovation, new management styles, and company cultures. In 2009, the association of small independent breweries in Slovakia was set up, which at the present time represents more than 40 small breweries (with an annual production of less than 200,000 hectoliters) with a market share of 5\% in Slovakia (Slovak Association of Beer and Malt Producers [11]). Slovak breweries are traditional employers particularly in regions with high levels of unemployment (Hurbanovo, Šariš, Banská Bystrica, Vyhne, Bytča). Increased demand for beer leads to increases in production and this helps the economy in the area of employment, with the sector providing about 17,600 jobs in total. About 1700 people work in the breweries themselves, and the supply sector indirectly employs a further 3800 people (Table 1) [15]. Of these, most work in the agricultural sector as well as in beer-related media and marketing (due to the fact that the brewing industry is an important sponsor of Slovak sports and sporting events). The most significant contribution to employment is, however, provided by the outlets for the product, public houses, restaurants, shops, etc.

Table 1. Indirect employment thanks to the beer industry in 2012.

\begin{tabular}{cc}
\hline Sector & Number of Jobs \\
\hline Agriculture & 1409 \\
Ancillary work & 72 \\
Packaging & 201 \\
Equipment and other industrial activities & 95 \\
Transport and storage & 614 \\
Media and marketing & 1183 \\
Services and other & 261 \\
Total & 3800 \\
\hline
\end{tabular}

\section{The Effect of Increases in the Tax Rates on Beer on the State Budget and Consumption}

Increases in the tax rate on beer have not, in the period considered, occurred as often as in the case of spirits and tobacco, caused also by the fact that the rate changed twice in one year. This increase could have been spread over a number of years, in which case the effect on the beer industry would not have been so great. In 2009, the rate did not change except to allow for the introduction of the Euro (Table 2, which shows the development of the excise duty rates on beer, from 1999 to 2009, in Slovak Crowns, and from then until the present in Euros, expressed per hectoliter).

A steady reduction in beer production in Slovakia began in 2004. In that year Slovakia produced $4,243,182$ hectoliters of beer, whereas in 2014 Slovak beer production had fallen to 2,857,424 hectoliters of beer for a tax take of $€ 55.4$. The free movement of beer across national borders occasioned by entry into the EU resulted in beer imports. While in 2004 there was a negative trade balance of $€ 8,946,100$, by 2014 this had increased to $€ 37,558,950$. This is also a result of stagnation in exports and a countervailing increase in imports from the Czech Republic and from previously non-traditional beer-exporting countries, especially Poland and Hungary [9]. Despite all the above and the increases in 
the tax rates, the contribution from beer to the state budget over the long term is falling or at least stagnant. Figure 2 indicates the years when there was a change in the tax rate on beer. The double increase in the tax rates on beer in 2003 led to, as a result, an increase in the contribution to the state budget, but only in the first year after their introduction. The falling trend was halted in 2007, but in the following year the contribution from the tax on beer fell again.

Table 2. Overview of the development of the tax rate on beer.

\begin{tabular}{|c|c|c|c|c|c|c|}
\hline & 1 Jan 1999 & 1 Jan 2000 & $1 \mathrm{Jan} 2003$ & 1 Aug 2003 & 1 Jan 2009 & 1 Jan 2012 \\
\hline Type of Beer & $\begin{array}{l}\text { Law No. } \\
180 / 1994 \\
\end{array}$ & $\begin{array}{l}\text { Law No. } \\
340 / 1999\end{array}$ & $\begin{array}{l}\text { Law No. } \\
391 / 2002\end{array}$ & $\begin{array}{l}\text { Law No. } \\
242 / 2003\end{array}$ & $\begin{array}{l}\text { Law No. } \\
465 / 2008\end{array}$ & $\begin{array}{l}\text { Law No. } \\
530 / 2011\end{array}$ \\
\hline \multicolumn{7}{|c|}{ Tax Rate } \\
\hline $\begin{array}{c}\text { Beer with degree strengt } \\
\text { up to and including } \\
11.6 \%\end{array}$ & $164 \mathrm{Sk} / \mathrm{hL}$ & $230 \mathrm{Sk} / \mathrm{hL}$ & & & & \\
\hline $\begin{array}{l}\text { Beer with degree } \\
\text { strength from } 11.7 \% \\
\text { to } 13.6 \% \text { inclusive }\end{array}$ & $360 \mathrm{Sk} / \mathrm{hL}$ & $400 \mathrm{Sk} / \mathrm{hL}$ & & & & \\
\hline \multirow[t]{2}{*}{$\begin{array}{c}\text { Beer with degree } \\
\text { strength from } 13.7 \%\end{array}$} & $423 \mathrm{Sk} / \mathrm{hL}$ & $470 \mathrm{Sk} / \mathrm{hL}$ & & & & \\
\hline & & & \multicolumn{4}{|c|}{ Basic Rate } \\
\hline All & & & $\begin{array}{l}30 \text { Sk per degree } \\
\text { strength per } h \mathrm{~L}\end{array}$ & $\begin{array}{l}50 \text { Sk per degree } \\
\text { strength per } \mathrm{hL}\end{array}$ & $\begin{array}{l}€ 1.65 \text { per degree } \\
\text { strength per } \mathrm{hL}\end{array}$ & $\begin{array}{c}€ 3.587 \text { per hL per } \\
\text { percent of actual } \\
\text { alcohol content }\end{array}$ \\
\hline & & & \multicolumn{4}{|c|}{ Reduced Rate } \\
\hline All & & & $\begin{array}{l}23 \mathrm{Sk} \text { per degree } \\
\text { strength per } \mathrm{hL}\end{array}$ & $\begin{array}{l}37 \text { Sk per degree } \\
\text { strength per } \mathrm{hL}\end{array}$ & $\begin{array}{l}€ 1.22 \text { per degree } \\
\text { strength per } \mathrm{hL}\end{array}$ & $\begin{array}{c}€ 2.652 \text { per } \mathrm{hL} \text { per } \\
\text { percent of actual } \\
\text { alcohol content }\end{array}$ \\
\hline
\end{tabular}

Sk, Slovak Crown; hL, hectoliters; Source: own calculations based on data from [16].

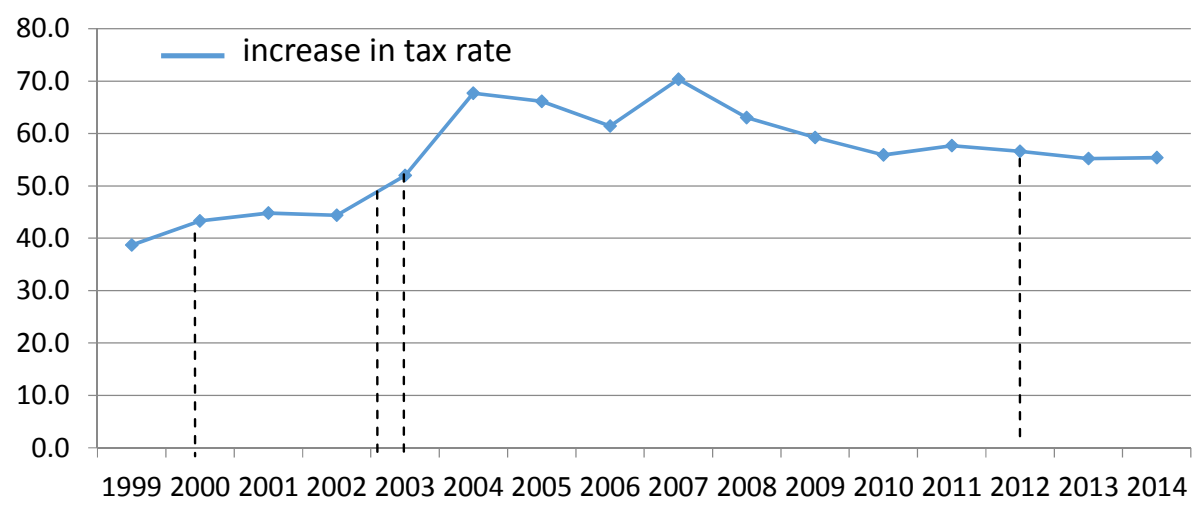

Figure 2. Development of the contribution to the state budget from the tax on beer in the years 1999 to 2014 in $€$ millions. Source: own calculations based on data from the Financial Directorate of the Slovak republic.

The production and consumption of beer affects the state budget not only via excise taxes, but also through income tax and value added tax (VAT). Thanks to all taxes and social security contributions, 
the total income in 2012 from the beer industry was on the level of $229 \mathrm{~m}$ Euros, which represents $1.83 \%$ of the total income to the state budget (Table 3).

The trend shown may be the result of:

- Saving by consumers - a too-high proportion of Slovaks have low incomes and have to consider carefully how they spend them;

- The possibility of substitution by other types of alcoholic drinks, such as spirits and wine;

- The high excise duty rate on beer;

- Changes of lifestyle which lead to consuming drinks with a low alcohol content;

- Severe penalties for those who drive under the influence of alcohol;

- Pressure from imports of similar products from abroad - this also depends on the activities of the food chains and the margins they negotiate from suppliers and those applicable on sales.

Table 3. Income to the state budget from the production and sale of beer in Euros millionchosen periods.

\begin{tabular}{cccc}
\hline Government Income & $\mathbf{2 0 0 8}$ & $\mathbf{2 0 1 0}$ & $\mathbf{2 0 1 2}$ \\
\hline Excise duties & 63 & 56 & 57 \\
VAT (hotels, restaurants, cafés) & 49 & 48 & 57 \\
VAT (retail outlets) & 45 & 48 & 45 \\
Income tax and pension and health contributions (brewing sector) & 7 & 8 & 9 \\
Income tax and pension and health contributions (other sectors) & 57 & 51 & 61 \\
Total & 221 & 211 & 229 \\
\hline
\end{tabular}

Note: Based on the data from [15].

Slovak brewers actively support the demands for "new" lifestyles. The general trend in Slovakia is a move from traditional $12 \%$-strength beers to the more and more common $10 \%$-strength ones with a lower alcohol content but a fuller flavor. Also, never in the history of beer-drinking has so much non-alcoholic beer been consumed. In 2014, 97,489 hectoliters of such beer were produced, which represents $3.4 \%$ of the total production. At the same time, the choice of such beers has been expanding (Source: Own calculations based on data from SLOVSTAT [9]).

The current hits are flavored beers (known as a radler or shandy), which are beers flavored, for example, with natural fruit juices. These are offered by both the large and small breweries and, in 2014, their production amounted to 355,954 hectoliters, which represents $12.5 \%$ of the total production. The effect of this is that beer consumption per head in Slovakia has fallen by 10 liters over just the last 10 years. In 2005, the consumption per head was 80 liters, and in 2014, only 70.4 liters. An important factor in increasing the tax rates is the possibility of substitution by other alcoholic drinks. From a more detailed examination of the structure of alcohol consumption in Slovakia over recent years, we have discovered that consumers have changed their preferences. Wine consumption (where the tax rate changed from the original $€ 0.17$ per liter of grape wine to $€ 0$ per liter of still wine) per head increased from 11.8 liters in 2005 to 21.2 liters in 2014, including fruit wines which increased from 1.6 liters to 3.4 liters per head (Table 4). This non-uniform scale of taxation for alcoholic drinks has led to changes in consumption, but the presumed aim of helping domestic wine producers has not been fulfilled, as the observed increase in consumption has led to a worsening of the negative trade balance in fresh wines, from $€-16,405,710$ 
in 2005 to $€-66,301,930$ in 2014 (Source: Ministry of Agriculture and Rural Development of the Slovak Republic [9]).

Table 4. The structure of alcohol consumption in liters per head in Slovakia from 1999 to 2014.

\begin{tabular}{lllllll}
\hline & $\mathbf{1 9 9 9}$ & $\mathbf{2 0 0 0}$ & $\mathbf{2 0 0 1}$ & $\mathbf{2 0 0 2}$ & $\mathbf{2 0 0 3}$ & $\mathbf{2 0 0 4}$ \\
\hline all alcoholic beverages & 108.4 & 111.0 & 110.9 & 115.0 & 110.1 & 104.4 \\
in terms of 100\% alcohol & 8.1 & 8.9 & 8.7 & 8.8 & 8.1 & 8.3 \\
spirits (40\%) & 10.0 & 9.7 & 9.1 & 8.8 & 7.4 & 8.7 \\
beer & 85.6 & 88.9 & 88.2 & 92.3 & 89.5 & 82.4 \\
all wines & 12.8 & 12.4 & 13.6 & 13.9 & 13.2 & 13.3 \\
\hline & $\mathbf{2 0 0 5}$ & $\mathbf{2 0 0 6}$ & $\mathbf{2 0 0 7}$ & $\mathbf{2 0 0 8}$ & $\mathbf{2 0 0 9}$ & \\
\hline all alcoholic beverages & 103.0 & 105.5 & 106.9 & 106.3 & 106.9 & \\
in terms of 100\% alcohol & 9.0 & 8.6 & 8.9 & 9.6 & 9.0 & \\
spirits (40\%) & 11.2 & 9.0 & 10.8 & 11.7 & 9.9 & \\
beer & 80.0 & 81.0 & 82.4 & 80.8 & 81.4 & \\
all wines & 11.8 & 15.5 & 13.7 & 13.8 & 15.6 & \\
\hline & $\mathbf{2 0 1 0}$ & $\mathbf{2 0 1 1}$ & $\mathbf{2 0 1 2}$ & $\mathbf{2 0 1 3}$ & $\mathbf{2 0 1 4}$ & \\
\hline all alcoholic beverages & 96.9 & 99.4 & 101.1 & 97.5 & 100.9 & \\
in terms of 100\% alcohol & 8.6 & 8.7 & 8.6 & 8.4 & 9.0 & \\
spirits (40\%) & 9.8 & 9.6 & 9.3 & 8.9 & 9.3 & \\
beer & 71.7 & 73.9 & 76.3 & 71.6 & 70.4 & \\
all wines & 15.4 & 15.9 & 15.5 & 17.0 & 21.2 & \\
\hline
\end{tabular}

Source: Statistical Office of the Slovak Republic [9].

\section{Conclusions}

Excise duties are levied only on specific items of consumption and therefore do not have to ensure a steady income for financing public expenditure. They are rather aimed at supporting social and market aims with the help of a better allocation of resources. They were introduced primarily in order to increase income for the state, but they are also seen as key methods of influence on people's behavior. The main principal is that rational and informed individuals make decisions on what to consume and what not to consume, but external costs (physical, psychical, or financial) should be included in the price given that not everybody is perfectly informed and rational.

Consumption and sales of beer are falling and this negative trend is influenced by, in addition to increases in the rates of indirect taxes, other factors, primarily the effects of the financial crisis, the social situation of the population, the buying habits of consumers, and poor harvests. In regards to beer, falling consumption and sales, in combination with indicators such as the yearly production in hectoliters and the number of breweries, are already alarming. In general, excise duties are an important component of prices, for example the tax on tobacco products, the tax on mineral oils, or the tax on alcoholic beverages. When setting the rates of excise duties one should always take into account the levels of such duties in neighboring countries to avoid "shopping tourism". Tax leaks arise in particular with regard to the excise duty on beer through shopping tourism and informal imports. Within the EU there are no obstacles or restrictions with regard to such purchases of products subject to excise duties. 
It is therefore necessary to proceed with care when taxing alcoholic drinks and to have a regard for domestic production and producers, who are significant employers (e.g., in the agricultural sector, hotel, and catering industries). The equality and fairness of tax treatment are important so as not to single out one type of alcoholic drink. It is important to realize that the zero rate of excise duty on still wines particularly benefits imported wines. A disproportionate increase in the rates of excise duty, such as the increase that occurred in 2003, results in a fall in consumption and stagnation of income to the state budget as well as a fall in employment.

\section{Acknowledgments}

The article was researched and written thanks to a scientific research project VEGA n. 1/0443/15. Tax policy and its impact on effective tax collection and elimination of tax evasion. Duration of the project is from 2015 to 2018 .

\section{Conflicts of Interest}

The authors declare no conflict of interest.

\section{References}

1. Ramsey, F.P. A Contribution to the Theory of Taxation. Econ. J. 1927, 37, 47-61.

2. Tomlinson, P.R.; Branston, J.R. The demand for UK beer: Estimates of the long-run on and off-trade beer price elasticities. Appl. Econ. Lett. 2013, 21, 209-214.

3. Frey, B.S. Excise Taxes: Economics, Politics and Psychology. Available online: http://www.bsfrey.ch/articles/413_05.pdf(accessed on 24 July 2015).

4. Berkhout, B.; Boersma, N.; Kruis G.; Poel P.; de Wit, W. The Contribution Made by Beer to the European Economy. Available online: http://www.brewersofeurope.org/uploads/mycmsfiles/documents/archives/publication(1).pdf (accessed on 17 November 2015).

5. Smith, A. Pojednání o Postatě a Púvodu Bohatství Národú; Liberální Institut: Praha, Czech Republic, 2001.

6. Hines, J.R., Jr. Excise Taxes. Available online: http://www.bus.umich.edu/otpr/WP2007-2.pdf (accessed on 24 July 2015).

7. Cnossen, S. 2010. The Economics of Excise Taxation. Available online: http://icepp.gsu.edu/files/2015/03/ispwp1018.pdf (accessed on 26 July 2015).

8. European Beer Pledge a Package of Responsibility Initiatives from Europe's Brewers, Second Year Report-November 2014. Available online: http://www.brewersofeurope.org/ uploads/mycms-files/documents/publications/2014/european-beer-pledge-2014-web.pdf (accessed on 17 November 2015).

9. The Ministry of Agriculture and Rural Development of the Slovak Republic and SLOVSTAT. Available online: http://www.slovstat.sk/ (accessed on 24 July 2015).

10. Cabadaj, P. Slovenské Pivovarníctvo v Toku Času; Agentúra MCP: Žilina, Slovak Republic, 2000.

11. Slovak Association of Beer and Malt Producers. Available online: http://www.slovenskepivo.sk/ index.php (accessed on 24 July 2015). 
12. Law No. 391/2002. Zákon z 18 Júna 2002, Ktorým sa Mení a Dopĺn̆a Zákon Národnej Rady Slovenskej Republiky č. 310/1993 Z. z. o Spotrebnej Dani z Piva v Znení Neskorších Predpisov; Národná Rada: Bratislava, Slovak Republic, 2002.

13. Law No. 310/1993. Zákon Národnej Rady Slovenskej Republiky z 15. Decembra 1993 o Spotrebnej Dani z Piva; Národná Rada: Bratislava, Slovak Republic, 1993.

14. Law No. 242/2003. Zákon z 27 Júna 2003, Ktorým sa Mení Zákon Národnej Rady Slovenskej Republiky č. 310/1993 Z. z. o Spotrebnej Dani z Piva v Znení Neskorších Predpisov; Národná Rada: Bratislava, Slovak Republic, 2003.

15. Berkhout, B.; Bertling, L.; Bleeker, Y.; de Wit, W.; Kruis, G.; Stokkel, R.; Theuws, R. The Contribution Made by Beer to the European Economy Full Report-December 2013. Available online: http://www.ey.com/Publication/vwLUAssets/EY_-_The_Contribution_made_by_Beer_to_ the_European_Economy/\$FILE/EY-The-Contribution-made-by-Beer-to-the-EuropeanEconomy.pdf (accessed on 17 November 2015).

16. Elektronická Zbierka Zákonov. Avaiable online: www.zbierka.sk (accessed on 24 July 2015).

(C) 2015 by the authors; licensee MDPI, Basel, Switzerland. This article is an open access article distributed under the terms and conditions of the Creative Commons Attribution license (http://creativecommons.org/licenses/by/4.0/). 